\title{
Unintended effects of statins from observational studies in the general population: systematic review and meta-analysis
}

\author{
Ana Filipa Macedo ${ }^{1,2^{*}}$, Fiona Claire Taylor ${ }^{1,3}$, Juan P Casas ${ }^{1,3,4}$, Alma Adler ${ }^{1}$, David Prieto-Merino ${ }^{5}$
} and Shah Ebrahim ${ }^{1,3}$

\begin{abstract}
Background: Efficacy of statins has been extensively studied, with much less information reported on their unintended effects. Evidence from randomized controlled trials (RCTs) on unintended effects is often insufficient to support hypotheses generated from observational studies. We aimed to systematically assess unintended effects of statins from observational studies in general populations with comparison of the findings where possible with those derived from randomized trials.

Methods: Medline (1998 to January 2012, week 3) and Embase (1998 to 2012, week 6) were searched using the standard BMJ Cohort studies filter. The search was supplemented with reference lists of all identified studies and contact with experts in the field. We included prospective studies with a sample size larger than 1,000 participants, case control (of any size) and routine health service linkage studies of over at least one year duration. Studies in subgroups of patients or follow-up of patient case series were excluded, as well as hospital-based cohort studies.

Results: Ninety studies were identified, reporting on 48 different unintended effects. Statins were associated with lower risks of dementia and cognitive impairment, venous thrombo-embolism, fractures and pneumonia, but these findings were attenuated in analyses restricted to higher quality studies (respectively: OR 0.74 ( $95 \% \mathrm{Cl} 0.62$ to 0.87 ); OR 0.92 (95\% Cl 0.81 to 1.03); OR 0.97 (95\% Cl 0.88 to 1.05); OR 0.92 (95\% Cl 0.83 to 1.02)); and marked heterogeneity of effects across studies remained. Statin use was not related to any increased risk of depression, common eye diseases, renal disorders or arthritis. There was evidence of an increased risk of myopathy, raised liver enzymes and diabetes (respectively: OR 2.63 (95\% Cl 1.50 to 4.61); OR 1.54 (95\% Cl 1.47 to 1.62); OR 1.31 (95\% Cl 0.99 to 1.73)).
\end{abstract}

Conclusions: Our systematic review and meta-analyses indicate that high quality observational data can provide relevant evidence on unintended effects of statins to add to the evidence from RCTs. The absolute excess risk of the observed harmful unintended effects of statins is very small compared to the beneficial effects of statins on major cardiovascular events.

Keywords: Statins, Unintended effects, Systematic review, Meta-analysis, Observational studies

\footnotetext{
*Correspondence: filipa_macedopt@hotmail.com

${ }^{1}$ Cochrane Heart Group, London School of Hygiene and Tropical Medicine, London, UK

${ }^{2}$ Faculty of Health Sciences, University of Beira Interior, Covilhã, Portugal

Full list of author information is available at the end of the article
} 


\section{Background}

Randomized controlled trials (RCTs) of statins have demonstrated their efficacy in preventing cardiovascular diseases (CVD) but much less information has been reported on their unintended effects [1-6]. In RCTs not all harmful effects can be easily anticipated, but even if measured, their reporting is inadequate [7]. Underreporting of unintended effects may affect the interpretation of the net clinical benefit, particularly among people at low cardiovascular risk.

The Cholesterol Treatment Trialists' (CTT) collaboration, an individual patient data overview of statin trials, has provided strong evidence of benefit across all risk categories from secondary prevention to primary prevention [8-11]. The CTT have confirmed an increased risk of myopathies (including rhabdomyolysis) and found no evidence of any increased risk of cancers $[10,11]$.

Two recent meta-analyses of randomized trials have suggested that statins might be associated with a 9\% increased relative risk of type 2 diabetes [12,13]. This led to new safety alerts from both the USA Food and Drugs Administration and the UK Medicines and Health-products Regulatory Agency (MHRA) [14,15]. Statin-induced liver dysfunction also occurs, but its incidence in the general population, in contrast to trials, is not well defined.

Since the start of widespread use of statins in clinical practice, numerous observational studies in North America and Europe have provided contradictory results on the effect of statins on a wide range of unintended effects [16-21]. The lack of coherence is not surprising given the inherent limitations in observational study designs, but is a source of considerable anxiety for the general public. Unfortunately, more robust evidence from RCTs on such unintended effects is often insufficient to support or refute hypotheses generated from observational studies, either because the relevant data were not collected or not reported [22-27].

Although potential biases and confounding have to be considered, population-based observational studies are more likely to include a broad representation of the population typically treated with statins. For these reasons, our objective was to systematically assess unintended effects of statins (with the exception of cancers) from observational studies in the general population.

\section{Methods}

\section{Criteria for inclusion of studies}

This review focused on observational studies of any unintended effects in general populations taking statins, compared with non-users. We included prospective studies with sample sizes larger than 1,000 participants, case control studies (of any size) and routine health service linkage studies of over at least one-year duration. Studies in subgroups of patients (for example, patients with familial hypercholesterolemia) or follow-up of patient case series were excluded, as well as hospital-based cohort studies (that is, cohort studies where the participants were selected among patients admitted to a certain hospital). Studies assessing lipid lowering drugs were included only if separate data on statins were presented, or if the study reported that statins accounted for the majority of the lipid lowering drugs used.

For purposes of this review, an unintended effect was any observational outcome reported (with the exception of cancers as there are no longer any serious concerns about excess cancer risk associated with statin use $[11,28]$ ), either favorable or untoward. Efficacy endpoints of reduction in low-density lipoprotein (LDL) cholesterol and total cholesterol were not considered but observational assessments of cardiovascular endpoints were made to test the validity of the approach.

\section{Search strategy}

We searched Medline (1998 to January 2012, week 3) and Embase (1998 to 2012, week 6), using the standard BMJ Cohort studies filter [29]. The search was limited to human studies, with no language restrictions (see Additional file 1: Text S1 for search strategy). Our search strategy aimed to detect observational studies that were concerned with statins used for treatment of cardiovascular diseases. We did not attempt to search with terms related to unintended consequences as specific difficulties arise when 'unintended effect' terms are added to a search strategy, because they are poorly reported, inadequately indexed, inconsistently described and can be new or unexpected at the time of searching [30]. Since no search filter seemed to have high sensitivity and specificity in both Medline and Embase databases [30], we supplemented our search with reference lists of all identified studies (including reviews), and contacted experts in the field asking for additional relevant articles.

\section{Study selection and data extraction}

One author (AFM) screened all titles and abstracts for studies that could potentially meet the inclusion criteria (Additional file 1: Text S2). Full articles were retrieved for further detailed assessment by the same reviewer, who then extracted onto a predesigned form information on study design, sample size, study location and duration, drug use and definition of exposure to statins, characteristics of participants, relevant outcomes and effect estimates, and degree of adjustment.

Two authors (FT and AA) checked a random sample of $10 \%$ of the titles and the numbers extracted. This approach aimed to assess the magnitude of the discrepancies, which might then lead to a decision to double-check all articles. Since no discrepancies were identified, no further duplicate checking was conducted. We also contacted 71 
authors to request additional information, ask for unpublished studies or clarify any uncertainty; 38 of them provided additional information.

\section{Assessment of risk of bias}

The risk of bias in observational studies was assessed using Newcastle-Ottawa Quality Assessment Scale (NOS) (Additional file 1: Text S3) according to the procedures recommended in the Cochrane Handbook of Systematic Reviews [31]. One author (AFM) assessed the methodological quality of all the selected studies.

The NOS includes a 'star system' in which a study is judged on three domains: representativeness of study group selection (four items); comparability of groups (two items); and ascertainment of either the exposure or outcome (three items). When any item of NOS (for example, adequacy of follow-up period) was not reported, a zero score was allocated. Studies score one star for each area addressed, with scores between 0 and 9 (the highest level of quality).

\section{Data analysis}

All meta-analyses used random effects models. For binary outcomes, we assumed interchangeability of odds ratio (OR), relative risk (RR) or hazard ratio (HR). Since the majority of unintended effects of statins are fairly rare, these measures will be similar [32]. Sensitivity analyses were carried out according to study design to explore the influence of different measures on the overall estimate of effect. The natural logarithms of effect estimates with 95\% confidence intervals were pooled across studies using DerSimonian and Laird random-effects methods. If more than one effect estimate was reported, the one derived from the most adjusted model and with the longest follow-up was used. Where estimates for a study were provided for men and women, these were pooled into a single estimate.

For continuous outcomes reported in different units, we used the adjusted mean change from baseline to followup, for exposed and unexposed, to obtain the standardized mean difference (SMD). Analysis was conducted using the metan command in Stata software (version 12.0 by Stata Press, 4905 Lakeway Drive, College Station, Texas).

\section{Heterogeneity}

Because this review included only observational studies, a greater level of heterogeneity was expected. We used $\mathrm{I}^{2}$ statistic to assess between-study heterogeneity. Sensitivity analyses were undertaken to explore the influence of different variables on the overall estimate of effect and as potential sources of heterogeneity: study design (cohort versus case-control studies), quality of the study (higher quality for NOS $\geq 8$ vs. NOS $<8$ ) and sample size (within three categories: $\leq 100,000,100,000$ to 1 million, >1 million).
We undertook this systematic review and meta-analysis according to PRISMA (Preferred Reporting Items for Systematic Reviews and Meta-Analyses) and MOOSE (Meta-analysis of Observational Studies in Epidemiology) guidelines during all stages of design, implementation and reporting (see Additional file 1: Text S4 and Additional file 1: Text S5 checklists). No original protocol for the review was produced.

\section{Results}

Figure 1 summarizes the study selection process (see Additional file 1: Text $\mathrm{S} 2$ for studies references). Additional file 1: Table S1 summarizes the characteristics of the 86 articles included, regarding study design, dataset, study population, sample size, follow-up duration and statin type. The analysis comprised 90 studies, 43 cohort studies and 47 case-control studies [17-20,33-114]. Only $6 \%$ of the studies were conducted outside Europe (51\%) or North America (43\%). The mean age of participants ranged from 47.0 to 81.2 years and among the 21 studies that reported data on ethnicity, the most commonly investigated ethnic group was Caucasians (75\%).

Forty-eight potential unintended effects of statins were identified, that is, described in at least one study. Definition of exposure to statins was assessed in numerous ways and included different types of statins. In 58 studies, exposure to statins was defined by at least one prescription or selfreported use during the study period.

A summary of the rating of risk of bias according to NOS is presented in Figure 2. The overall quality of the studies was high (mean score 7.1 out of a total possible of nine). All but six studies received six to nine "stars" in the NOS. The mean value of "assigned stars" was 7.4 (range 5 to 9) in the cohort studies and 6.8 (range 3 to 8 ) in the case control studies.

\section{Meta-analysis}

The summary effect estimates of each study were pooled to give a total estimate of risk for each outcome (Figure 3). Effect sizes from meta-analyses of RCTs or single large RCTs were also plotted when available for comparative purposes.

\section{Neurologic and psychological effects}

Thirteen studies with 2,762,899 participants examined the association between use of statins and incidence of any combination of the dichotomous outcomes: dementia, cognitive impairment without dementia (CIND) or Alzheimer's disease (AD). An odds ratio of 0.70 (95\% CI 0.59 to 0.83 ) was observed for those participants exposed to statins; but the higher quality studies showed an attenuated effect (OR 0.74, 95\% CI 0.62 to 0.87 ) compared with the lower quality studies (OR $0.53,95 \%$ CI 0.37 to 0.92 ) (Additional file 1: Figure S1-A). Marked between-study heterogeneity as indicated by high $\mathrm{I}^{2}$ values was observed 


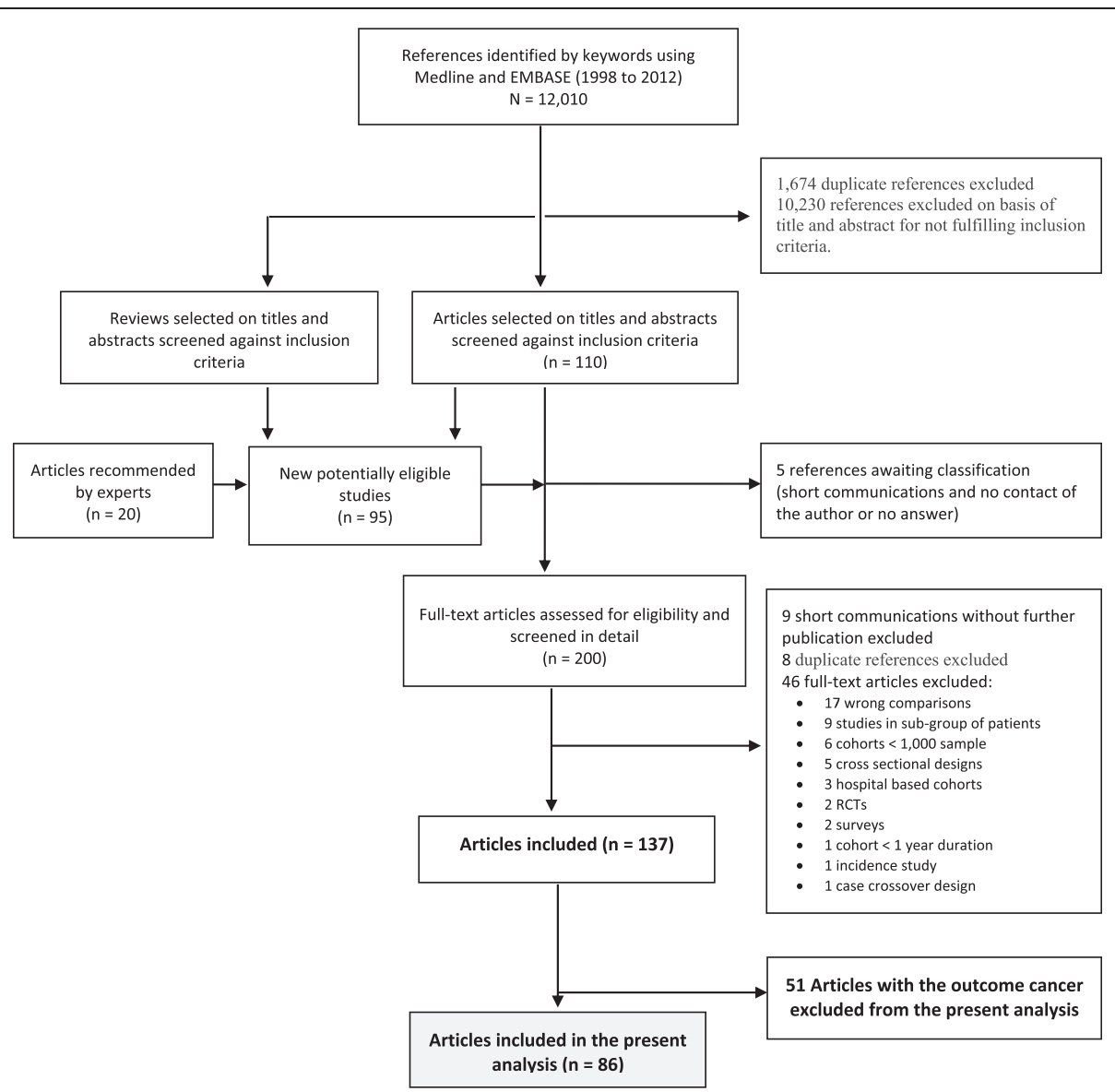

Figure 1 Flow chart for identifying eligible studies. The search strategy yielded 12,010 publications, of which 1,674 were duplicates and 10,230 references were not eligible based on abstract and title review. We systematically searched the reference lists of the remaining 110 eligible articles and of 33 reviews, and contacted experts. Ninety-five additional studies were identified that were not captured with our initial search strategy. Of this total, five references of short communications await classification because we were unable to contact the author or received no answer regarding a possible publication. Full papers were obtained for 200 references. From these, 63 were excluded for not fulfilling inclusion criteria. Of the identified 137 references, 51 assessed statin risk of cancer and were excluded from the present analysis; we focused on the remaining 86 references.

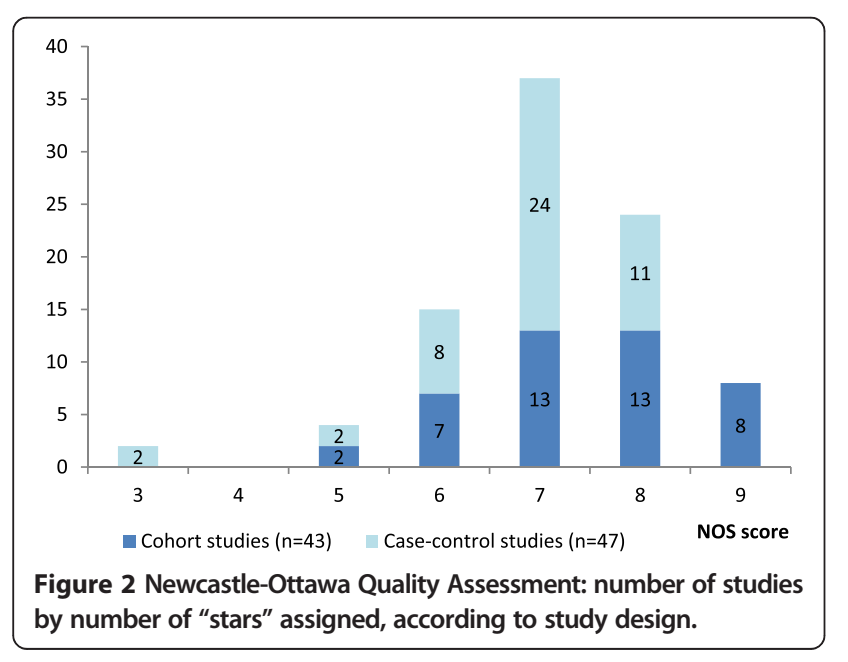

which was not explained by stratifying by study quality. Similar association of statin use was observed when the analysis was restricted to incident Alzheimer's disease ( $\mathrm{OR}=0.61 ; 95 \% \mathrm{CI} 0.50$ to 0.75 ), dementia (not Alzheimer's) (OR $=0.73 ; 95 \%$ CI 0.61 to 0.88 ) and for incident Parkinson's disease $(\mathrm{OR}=0.84 ; 95 \% \mathrm{CI} 0.74$ to 0.95$)$. One case control study recruited prevalent cases of Parkinson's disease and observed a stronger risk reduction $(\mathrm{OR}=0.37 ; 95 \% \mathrm{CI} 0.19$ to 0.72 ) [56]. This study was excluded from the pooled analysis because it was responsible for significant heterogeneity between studies $\left(\mathrm{I}^{2}=63.2 \%\right.$ vs. $\left.\mathrm{I}^{2}=51.8 \%\right)$.

Improved cognitive test scores were observed in two studies: standardized mean difference of 0.18 (95\% CI 0.09 to 0.27 ) [19,101]. In a cohort study of 21 years, statin treatment was related to better performance in episodic memory and psychomotor speed tests (5 to $8 \%$ relative differences) [96]. 


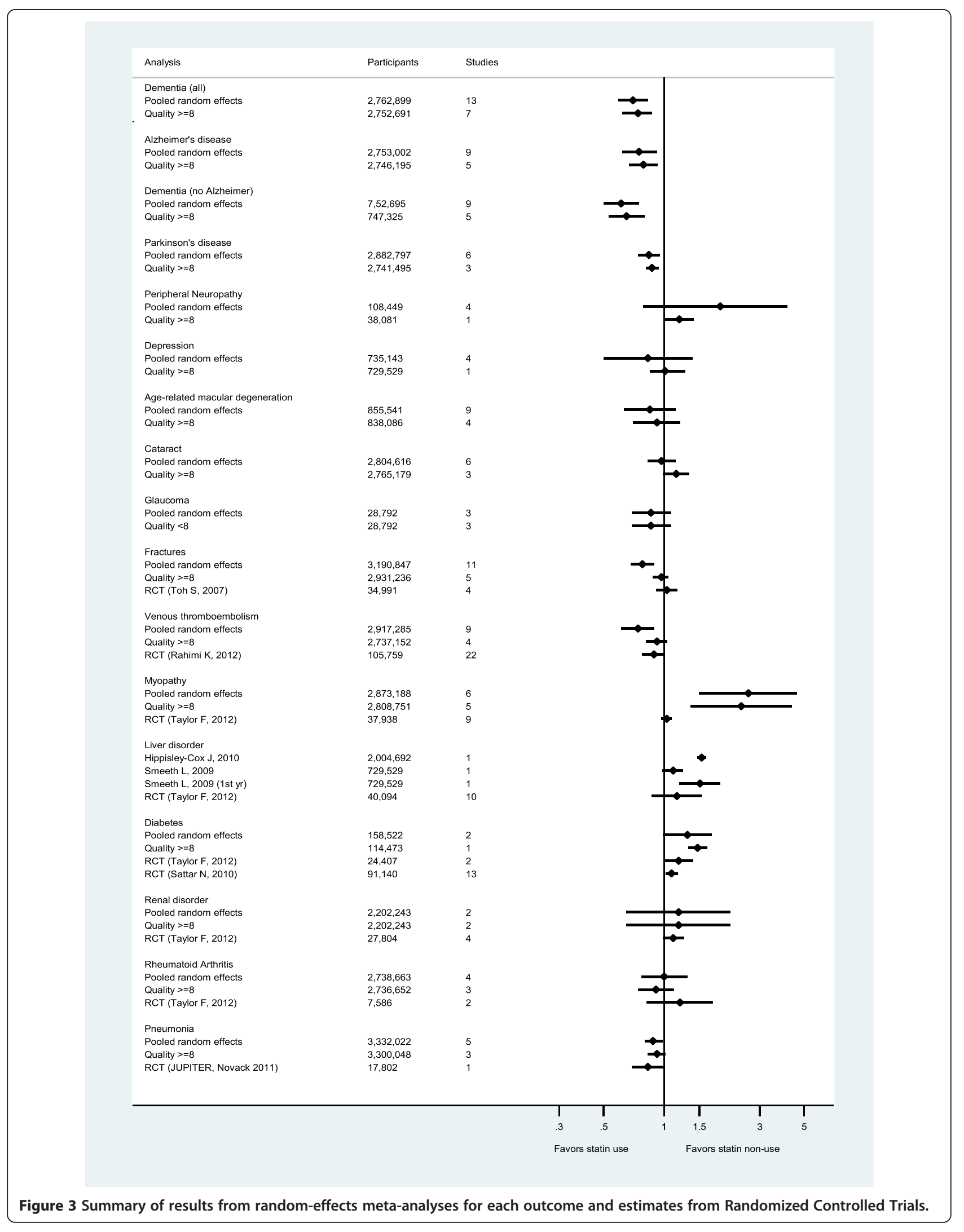


Four studies $(108,449$ participants) reported on peripheral neuropathy and no strong evidence of increased risk was observed $\left(\mathrm{OR}=1.91 ; 95 \%\right.$ CI 0.89 to $4.41, \mathrm{I}^{2}=73.9 \%$, random effects model) $[33,39,48,49]$. Studies of low quality $(\mathrm{NOS}<8)$ showed a more pronounced association $(\mathrm{OR}=2.57 ; 95 \%$ CI 1.04 to 6.32$)[33,48,49]$.

Four studies (735,143 participants) reported on depression and suicidal behavior $[17,70,94]$. No evidence of increased risk was seen for these endpoints $(\mathrm{OR}=0.83$; 95\% CI 0.50 to 1.39 ) and this result was consistent across sub-groups.

\section{Eye disorders}

The outcomes comprised age-related macular degeneration (AMD), cataract and glaucoma. No strong evidence of association was observed in the pooled analysis using random effects model for any of these outcomes (Figure 3).

\section{Venous thromboembolism (VTE)}

Using a random effects model, a relative risk reduction of VTE, which favored statin treatment by $26 \%$, was observed $(\mathrm{OR}=0.74 ; 95 \%$ CI 0.61 to 0.89$)$. There was marked heterogeneity of effects across studies $\left(\mathrm{I}^{2}=84.1 \%\right)$. Analysis restricted to the four studies with higher quality (NOS $\geq 8$ ), including 2,737,152 participants, showed marked attenuation of the risk reduction $(\mathrm{OR}=0.92$; 95\% CI 0.81 to -1.03$)$.

\section{Fractures}

A relative risk reduction of fractures on statin treatment by $22 \%$ was observed (OR $=0.78 ; 95 \%$ CI 0.68 to $0.89, \mathrm{I}^{2}=91.2 \%$ ) but this was markedly attenuated when analysis was restricted to the five higher quality studies $(\mathrm{OR}=0.97 ; 95 \% \mathrm{CI} 0.88$ to 1.05$)$ and in the cohort studies $(\mathrm{OR}=0.85 ; 95 \% \mathrm{CI} 0.72$ to 1.00$)$ and in the three largest studies $\left(\mathrm{OR}=0.98 ; 95 \% \mathrm{CI} 0.95\right.$ to $\left.1.02 ; \mathrm{I}^{2}=0.0 \%\right)$ (Additional file 1: Figure S1-B).

\section{Myopathy}

A markedly increased risk of myopathy was observed $\left(\mathrm{OR}=2.63\right.$; 95\% CI 1.50 to $\left.4.61, \mathrm{I}^{2}=98.2 \%\right)$, which was consistent in sub-groups by study design, quality and size but the heterogeneity remained. In a single study, statin treatment was related to an average reduction in grip strength $(\mathrm{kg})$ from baseline of $0.24 \mathrm{~kg}$ (men) to $0.52 \mathrm{~kg}$ (women) [34]. No evidence of any increase in myopathy in primary prevention RCTs was found $(R R=1.03,95 \%$ CI 0.97 to $1.09, \mathrm{I}^{2}=41 \%$ ) [1]. CTT results demonstrated an increased risk of myopathy conferred by statins, and an observed excess of rhabdomyolysis of 1 (SE 1) per 10,000 in the 21 trials of standard statin regimens versus control (14 vs. 9 cases) [9].

Incidence rates of events according to exposure and outcome definition were examined (Table 1), and in prospective studies ranged from 2.30 to 9.06 per 10,000 person-years, with an excess rate between 2.10 and 5.77 per 10,000 person-years. Two studies only reported data on absolute risk of myopathy (26 and 11 per 10,000 participants), corresponding to an estimated excess risk of 22 and 8 per 10,000 participants, respectively $[55,94]$. One study presented what the authors called "prevalence rates" of any myopathic event, in diabetic and nondiabetic subjects, with rates of 242 and 268 per 10,000 person-years, respectively [78].

\section{Liver disorder and raised liver enzymes}

The definition of hepatic disorders was ascertained by medical codes for "acute liver disease" in the study by Smeeth et al. [94], and by an ALT $\geq 120$ IU/l among patients without chronic liver disease in the study by Hippisley-Cox et al. [55] Both studies observed an increased risk of liver disorders. Smeeth et al. found an increased risk of incident liver disease in the first year after the index date (HR 1.51; 99\% CI 1.19 to 1.91 ), but little or no increased risk after this time (HR 1.11; 99\% CI 0.98 to 1.24); and Hippisley-Cox et al. found an increased risk of liver enzyme changes $(\mathrm{HR}=1.54 ; 95 \% \mathrm{CI} 1.47$ to 1.62). Results were not pooled across the two definitions of liver disorders. Incidence of liver disorders in these two large prospective studies ranged from 44 to 120 per 10,000 participants, corresponding to an estimated excess risk of 16 and 50 per 10,000 participants, respectively (Table 1 ) $[55,94]$. In two additional studies, both gallstones and cholecystectomy events were less common in patients treated with statins (Additional file 1: Figure S2).

\section{Renal disorder}

No evidence of increased risk of renal disorder was observed $\left(\mathrm{OR}=1.18 ; 95 \% \mathrm{CI} 0.65\right.$ to $\left.2.14, \mathrm{I}^{2}=99.2 \%\right)$. The observed heterogeneity might be due to different outcome definitions. The study by Hippisley-Cox et al. found an increased risk of "acute renal failure" ascertained by medical codes [55]; while the study by Sukhija et al. [100] found a protective effect of statins on renal dysfunction. A moderate rise in urinary albumin excretion (UAE) in statin users $(+12.1 \%)$ compared with non-users $(+3.6 \%)$, which was more pronounced with higher dose or duration of statin treatment has been reported, but with no change in glomerular filtration rate (GFR) [35].

\section{Type 2 diabetes}

Overall, weak evidence of an increased risk of type 2 diabetes mellitus (T2DM) was observed $(\mathrm{OR}=1.31$; $95 \% \mathrm{CI}$ 0.99 to $1.73, \mathrm{I} 2=72.1 \%$ ). One cohort study (Women's Health Initiative) of higher quality and larger sample size found stronger evidence of an increased risk of selfreported T2DM $(\mathrm{OR}=1.47 ; 95 \% \mathrm{CI} 1.32$ to 1.64$)$ for the groups of women who reported statin use at baseline and three years later [41]. The cumulative incidence of T2DM 
Table 1 Incidence rate and excess risk attributable to statins for myopathy, hepatic disorder and diabetes

\begin{tabular}{|c|c|c|c|c|}
\hline Author, year & $\begin{array}{l}\text { Incidence/ } 10.000 \\
\text { person-years or } \% \\
(95 \% \mathrm{Cl})\end{array}$ & $\begin{array}{l}\text { Excess risk/10.000 } \\
\text { person-years or } \%\end{array}$ & Exposure definition & Outcome definition \\
\hline \multicolumn{5}{|l|}{ Myopathy } \\
\hline \multirow[t]{2}{*}{ Gaist et al. [50] } & 2.30 & \multirow[t]{2}{*}{2.10} & \multirow{2}{*}{$\begin{array}{l}\text { One prescription and additional } \\
30 \text { days supply }\end{array}$} & \multirow{2}{*}{$\begin{array}{l}\text { Medical codes for myopathic events } \\
\text { and validation by independent } \\
\text { blind review of medical records }\end{array}$} \\
\hline & (1.20 to 4.40$)$ & & & \\
\hline \multirow[t]{2}{*}{ Hippisley-Cox et al. [55] } & $0.26 \%$ & \multirow[t]{2}{*}{$0.22 \%$} & \multirow[t]{2}{*}{ First prescription after January 2002} & \multirow{2}{*}{$\begin{array}{l}\text { Medical codes for moderate or serious } \\
\text { myopathic events (myopathy or } \\
\text { rhabdomyolysis or a CK } \geq 4 X \text { ULN) }\end{array}$} \\
\hline & (0.24\% to $0.28 \%)$ & & & \\
\hline \multirow[t]{2}{*}{ McClure et al. [77] } & 9.06 & \multirow[t]{2}{*}{5.77} & \multirow{2}{*}{$\begin{array}{l}\text { One prescription during the } \\
\text { study period }\end{array}$} & \multirow{2}{*}{$\begin{array}{l}\text { Medical codes for myopathy and } \\
\text { CK } \geq 10 X \text { ULN }\end{array}$} \\
\hline & (n.r.) & & & \\
\hline \multirow[t]{2}{*}{ Smeeth et al. [94] } & $0.11 \%$ & \multirow[t]{2}{*}{$0.08 \%$} & \multirow[t]{2}{*}{ First prescription after January 1995} & \multirow[t]{2}{*}{ Medical codes for myositis or myolysis } \\
\hline & (n.r.) & & & \\
\hline \multicolumn{5}{|l|}{ Hepatic disorder } \\
\hline \multirow[t]{2}{*}{ Hippisley-Cox et al. [55] } & $1.20 \%$ & \multirow[t]{2}{*}{$0.50 \%$} & \multirow[t]{2}{*}{ First prescription after January 2002} & \multirow{2}{*}{$\begin{array}{l}\text { ALT } \geq 120 \text { IU/I among patients without } \\
\text { chronic liver disease }\end{array}$} \\
\hline & $(1.13 \%$ to $1.22 \%)$ & & & \\
\hline Smeeth et al. [94] & $1.60 \%$ & $0.30 \%$ & First prescription after January 1995 & Medical codes for acute liver disease \\
\hline \multirow[t]{2}{*}{ First year only } & $0.44 \%$ & \multirow[t]{2}{*}{$0.16 \%$} & & \\
\hline & (n.r.) & & & \\
\hline \multicolumn{5}{|l|}{ Diabetes } \\
\hline \multirow[t]{2}{*}{ Culver et al. [41] } & $6.25 \%$ & \multirow[t]{2}{*}{$2.25 \%$} & \multirow{2}{*}{$\begin{array}{l}\text { One prescription at the first screening } \\
\text { interview and three-year follow-up }\end{array}$} & \multirow{2}{*}{$\begin{array}{l}\text { Self-report of a new physician } \\
\text { diagnosis of treated diabetes }\end{array}$} \\
\hline & (5.71\% to $6.84 \%)$ & & & \\
\hline Jick et al. [59] & n.a. & n.a. & $\begin{array}{l}\text { Two prescriptions one year before } \\
\text { index date }\end{array}$ & $\begin{array}{l}\text { Medical code for first diagnosis of } \\
\text { diabetes plus more than two } \\
\text { prescriptions for a hypoglycaemic } \\
\text { agent or three records of diet } \\
\text { management }\end{array}$ \\
\hline
\end{tabular}

ALT, alanine transaminase; CK, creatine kinase; n.a., not applicable in a nested case control study; n.r., confidence intervals not reported; ULN, upper limit of normal.

after three years of statin treatment was $6.25 \%$, corresponding to an excess risk of $2.25 \%$ (Table 1). This excess risk corresponds to a number needed to harm $(\mathrm{NNH})$ of 44 patients (95\% CI 35 to 60) for an additional case of diabetes over three years of statin treatment. Conversely, a nested case-control study using data from the General Practice Research Database (GPRD) found no association between statin use and T2DM development $(\mathrm{OR}=1.10$; $95 \%$ CI 0.83 to 1.46 ) [59].

\section{Rheumatoid arthritis and osteoarthritis}

No increased risk of rheumatoid arthritis or osteoarthritis was observed $\left(\mathrm{OR}=1.00\right.$; $95 \% \mathrm{CI} 0.77$ to $\left.1.30, \mathrm{I}^{2}=75.7 \%\right)$, which was confirmed in the two cohort studies with higher quality and sample size $(\mathrm{OR}=1.00$; $95 \% \mathrm{CI} 0.93$ to 1.08), while the two case control studies reported conflicting results (Additional file 1: Figure S1-C).

One cohort study reported on the progression of osteoarthritis and observed a protective effect of statins $(\mathrm{OR}=0.43 ; 95 \% \mathrm{CI} 0.25$ to 0.77$)$ [38]. No association between statin treatment and other outcomes with a possible immune mechanism (psoriasis, multiple sclerosis or systemic lupus erythematosus) was found (Additional file 1: Figure S2).

\section{Pneumonia}

A risk reduction of pneumonia was observed $(\mathrm{OR}=0.88$; $95 \%$ CI 0.80 to $0.98, \mathrm{I}^{2}=61.7 \%$ ), which was attenuated in analysis restricted to the three cohort studies with higher quality (NOS $\geq 8)(\mathrm{OR}=0.92 ; 95 \%$ CI 0.83 to 1.02$)$ (Additional file 1: Figure S1-C) [46,64,94]. Smeeth et al. [94] and Fleming et al. [46] also found no association between statin treatment and infection-related outcomes, such as acute bronchitis, acute respiratory infections, other respiratory tract infections (no pneumonia) or urinary tract infections, (Additional file 1: Figure S2).

\section{Other possible unintended effects}

No evidence of excess risk of other possible unintended effects that have been suggested was found (Additional file 1: Figure S2). Expected risk reductions were observed for stroke and myocardial infarction. Some unexpected risk reductions were found. Current statin use was associated with a reduced risk of chronic obstructive pulmonary 
disease (COPD) (OR $=0.45$; 95\% CI 0.25 to 0.80 ) in a single study of only one-year duration in which the role of smoking was unclear [88]. The other studies reporting protective associations between statin use and low urinary tract symptoms, subarachnoid hemorrhage and intracerebral hemorrhage were all small with poor assigned quality $(\mathrm{NOS} \leq 6)[84,99,110]$.

\section{Discussion}

We found no increased risk of peripheral neuropathy, depression, common eye diseases, renal disorders or arthritis associated with taking statins. Studies of higher quality did not show previously reported protective effects of statins on fractures, venous thrombo-embolism or pneumonia. Lower odds of dementia and cognitive impairment were associated with statin use but were attenuated in higher quality studies indicating that they may not be robust. There was evidence of an increase in myopathy, raised liver enzymes and diabetes. The pooled observational findings were heterogeneous which might reflect differences in study quality, the populations studied and how statin exposure and effects were measured.

Observational studies of effects of drugs are beset with problems of 'confounding by indication' which results in people on treatment often having worse outcomes than those not on treatment simply because they are sicker. In the studies reviewed here, investigators attempted to obtain comparable groups by a range of methods including simple matching, controlling for potential confounders and propensity score matching. None of these methods are as efficient as randomization in controlling for selection bias and confounding but for rare outcomes and to study typical patients using drugs in the general population, observational studies provide the only means of making assessments. Moreover, population-based observational studies provide reliable estimates of the incidence of effects experienced in the general population, important in evaluating the public health impact of an intervention, as this usually cannot be done reliably using randomized trial data (because of limited power and differences between trial samples and general populations).

\section{Comparison of results with randomized trials}

For unintended effects that had been reported in RCTs, the effect estimate derived from observational studies was compared with RCT findings to determine the extent to which observational studies were capable of obtaining robust findings. This approach has been used previously [94]; and a recent study found no difference in the risk estimate of adverse effects of interventions derived from meta-analyses of RCTs and meta-analyses of observational studies, suggesting that these may be estimated reliably from observational data [115]. For this comparison we used results from published data from the CTT collaboration, systematic reviews from the Cochrane collaboration or recent systematic reviews on specific unintended effects that superseded either of these sources. Pooled or single RCT estimates are presented below the observational pooled estimates for the higher quality studies and indicate that in the RCT and observational findings were broadly similar (Figure 3), although RCT estimates tended to be more conservative. Consistency between observational and RCT findings suggests that confounding by indication is unlikely to invalidate the observational results, particularly for estimates obtained from large, better quality observational studies.

Evidence from recent systematic reviews and metaanalyses of randomized trials showed no differences in risk of psychological outcomes [116], fractures [117], acute renal failure [118], arthritis [1] or venous thromboembolism [119]. A recent meta-analysis of randomized trials and prospective cohort studies concluded that long-term data may support a beneficial effect of statins in the prevention of dementia [120] and another review of statins and cognitive impairment found no strong evidence of an association with Alzheimer disease or cognitive function [121].

A recently published meta-analysis of observational studies also found a similar reduction in the likelihood of pneumonia associated with statin use [122], in line with randomized findings from the Justification for the Use of Statins in Primary Prevention: an Intervention Trial Evaluating Rosuvastatin (JUPITER) trial [123]. Statin use may be a surrogate marker for better health which may confound the observed association with pneumonia [124].

RCTs in both primary and secondary prevention found an increased risk of T2DM (OR 1.18; 95\% CI 1.01 to 1.39 and $\mathrm{OR}=1.09$; $95 \% \mathrm{CI} 1.02$ to 1.17$)[1,12]$. This association appears to be higher with intensive-dose statin therapy and among elderly subjects [125], and is strongly associated with baseline fasting blood glucose and coexisting CVD risk factors, suggesting that statins raise blood glucose by a small amount, moving people from below to above the diagnostic threshold [126]. In a recent observational cohort study, atorvastatin and simvastatin compared with pravastatin were associated with an increased risk of new onset diabetes [127]. In a new analysis of the JUPITER primary prevention trial, the cardiovascular and mortality benefits of statin therapy exceeded the risk of developing diabetes even in people at high risk of developing diabetes [128]. Although the mechanism underlying the increase in new onset T2DM in patients treated with statins is unknown, it is possible that statins interfere with insulin signaling, leading to hyperinsulinemia, insulin resistance, metabolic syndrome, pre-diabetes and diabetes [129-131].

The apparent protective effect of statin use on cognitive function was linked with ApoE4 genotype in one study among individuals $<80$ years [68]. Further research is 
needed to assess the possible interaction of statin use and ApoE genotype on risk of AD or dementia.

Our analysis gave higher estimates than RCTs for myopathy which may reflect differences in the diagnostic criteria used and the populations studied. Myopathy is more likely to occur with higher doses of statins and in situations that raise statin blood levels, including advanced age, frailty, deterioration of renal function and the presence of interacting drugs [132], all common exclusions for RCTs. A blinded, controlled trial among healthy statin-naïve people showed that high-dose atorvastatin for six months had no effect on muscle strength or exercise performance but confirmed that statins increase muscle complaints and increased average creatine kinase, suggesting that statins produce mild muscle injury even among asymptomatic subjects [133]. An observational study using military personnel records found that musculoskeletal conditions, arthropathies, injuries and pain were more common among statin users than among propensity score-matched nonusers [134].

No increased risk of renal disease attributable to statin treatment was found in our review. Recent systematic reviews of trials have demonstrated lower mortality and cardiovascular events in persons with early stages of chronic kidney disease (CKD) on statins, but little or no effect in persons receiving dialysis, and uncertain effects in kidney transplant recipients $[135,136]$.

We found an increased risk of liver disorders, although outcome definition was heterogeneous across studies. With the exception of statin-induced transaminase elevation, large statins trials have not shown an increase in the incidence of liver diseases. In a systematic review of 21 randomized trials, elevated transaminases occurred with an excess rate of 7 per 10,000 person-years but liver disease was rare (0.05 per 10,000 person-years) [137]. This was confirmed in a larger network meta-analysis [138]. Routine monitoring of liver function after starting a statin is no longer recommended [14].

\section{Limitations and strengths}

One major strength of our systematic review is the inclusion of a large number of observational studies in general populations and a wide range of potential unintended effects of statins. Therefore, our analysis is more likely to include a broad representation of the population at-risk, and may reflect better the nature and frequency of unintended effects experienced in clinical practice.

Despite the many positive aspects, observational research is prone to bias and confounding. The results from the studies included in this meta-analysis could be influenced by a "healthy-user" effect and closer monitoring. We explored the robustness of our results across three dimensions: study design, sample size and quality of the studies but heterogeneity of the pooled observational findings could not be explained by them, and may reflect the different populations studied, how the statin exposure was measured or different outcome definitions. It was not possible to assess the consistency of outcome definitions between studies which is an inherent limitation of systematic reviews based on published data. We also recognize the limitation of having a single reviewer assessing all data extraction and validity; although no discrepancies were identified in a random sample of $10 \%$ of the titles and the numbers extracted. Publication bias is a particular threat to the validity of meta-analysis of observational studies. Although we contacted authors asking for unpublished studies, publication bias is possible since observational studies with significant outcomes are more likely to be published and, therefore, over-represented in our meta-analysis. The pooled effect sizes may potentially be exaggerated by this bias.

A further limitation is the difficulty in keeping this review up to date given the high level of publication on statins. In recognition of this we conducted a rapid update search of Medline (January 2012 to February 2014, terms: statins, humans, core medical journals, 141 hits) and have incorporated substantive new findings in relevant sections of our discussion.

Some unintended effects (for example, ventricular arrhythmia, intracerebral hemorrhage) were not covered in this meta-analysis as they were not reported in populationbased studies, but from case reports and clinical case series which provide weaker evidence of causal association. A recent meta-analysis including RCTs and observational studies (mainly secondary analysis of RCTs and small studies in subgroups of patients with atrial fribrillation or acute ischemic stroke) found no association between statin exposure and intracerebral hemorrhage, consistent across study designs [139].

\section{Implications for clinical practice}

Statins are widely used in clinical practice and their efficacy for secondary prevention of CVD is well founded, but their expanding use in primary prevention in low-risk individuals has to be balanced against the risk of 'overmedicating' the general population [140]. This assumes particular importance since findings from a recent cohort of 3.8 million general population patients of UK Clinical Practice Research Datalink (CPRD) showed substantive overuse of statins in low CVD risk and underuse in high CVD risk [141]. Given that several trials are currently evaluating the effects of a polypill on risk factor levels, the use of statins is likely to increase to a much wider section of the population (whether by age or by cut-off on absolute risk) [142]. Thus, accurate evidence on the potential unintended effects of statins is of public health relevance. 
The observed unintended effects, most importantly myopathy and elevated liver enzymes, are rare and more likely to occur with higher doses of statins. The possible increased risk of developing T2DM has resulted in surveillance recommendations.

\section{Implications for future research}

Reporting of unintended effects in RCTs is not done consistently and failure to report such findings introduces bias into evaluations of the benefits and harms of treatments. Considerable adverse event data are collected in most RCTs but are not readily available to include in systematic reviews. Future research in this area will need to engage with pharmaceutical companies to obtain relevant data to enable unbiased assessments of the true levels of common unintended effects of statins.

\section{Conclusion}

Our systematic review and meta-analyses indicate that high quality observational data can provide reliable and relevant evidence on unintended effects of statins to add to the evidence from RCTs for health care guidance. Comparisons of the observational findings with RCTs, where possible, showed similar estimates, indicating that our approach is capable of making plausible inferences on unintended effects. The absolute excess risk of the observed harmful unintended effects of the statin class of drugs is very small compared to the beneficial effects of statins on major cardiovascular events.

\section{Ethical approval}

An ethics statement was not required for this work.

\section{Additional file}

Additional file 1: Figure S1 A. Summary of results from primary meta-analyses for each outcome: pooled fixed effects and subgroup analysis by quality of the studies, sample size and study design. Figure S1 B. Summary of results from primary meta-analyses for each outcome: pooled fixed effects and subgroup analysis by quality of the studies, sample size and study design (continued). Figure S1 C. Summary of results from primary meta-analyses for each outcome: pooled fixed effects and subgroup analysis by quality of the studies, sample size and study design (continued). Figure S2. Summary of results from primary meta-analyses for other possible unintended outcomes: pooled random effects. Table S1. Characteristics of the studies included. Text S1. Search strategy overview. Text S2. Study references. Text S3. Newcastle-Ottawa Quality Assessment Scale. Text S4. PRISMA checklist. Text S5. MOOSE checklist. Figure S3 to Figure S19. Pooled random effects for each outcome.

\section{Abbreviations}

AD: Alzheimer's disease; AMD: Age-related macular degeneration; CIND: Cognitive impairment without dementia; COPD: Chronic Obstructive Pulmonary Disease; CTT: The Cholesterol Treatment Trialists' collaboration; CVD: Cardiovascular diseases; GPRD: General Practice Research Database; HR: Hazard ratio; LDL: Low-density lipoprotein; MHRA: Medicines and Health-products Regulatory Agency; MOOSE: Meta-analysis of Observational Studies in Epidemiology; NOS: Newcastle-Ottawa Quality Assessment Scale; OR: Odds ratio; PRISMA: Preferred Reporting Items for Systematic Reviews and Meta-Analyses; RCT: Randomized controlled trial; RR: Relative risk; SMD: Standardized mean difference; T2DM: Type 2 diabetes mellitus; VTE: Venous thromboembolism.

\section{Competing interests}

Ana Filipa Macedo conducted this work during a sabbatical at London School of Hygiene and Tropical Medicine and was employed by the University of Beira Interior, Portugal. She is now employed by Boehringer-Ingelheim which does not produce any statin or other lipid lowering drug. All other authors have no relevant conflicts of interest to declare.

\section{Authors' contributions}

SE originated the idea, and prepared the review and controlled the content. AFM assessed the relevance and quality of papers, extracted data, wrote to authors, analyzed data and prepared the manuscript. FT originated the idea, and helped screen the relevance and quality of papers. JP contributed to the interpretation of results and revised the manuscript critically for important intellectual content. AA helped screen the quality of the data extracted. DP contributed to the statistical analysis. All authors read and approved the final manuscript.

\section{Acknowledgements}

The authors would like to acknowledge all the investigators for their help in providing the relevant articles which were not identified in our search strategy or could not be found in UK public libraries.

This research received no funding. No funding bodies played any role in the design, writing or decision to publish this manuscript.

\section{Author details}

${ }^{1}$ Cochrane Heart Group, London School of Hygiene and Tropical Medicine, London, UK. ${ }^{2}$ Faculty of Health Sciences, University of Beira Interior, Covilhã, Portugal. ${ }^{3}$ Department of Non-communicable Disease Epidemiology, London School of Hygiene and Tropical Medicine, London, UK. ${ }^{4}$ Institute of Cardiovascular Science, University College London, London, UK. ${ }^{5}$ Department of Medical Statistics, London School of Hygiene and Tropical Medicine, London, UK

Received: 28 October 2013 Accepted: 28 February 2014 Published: 22 March 2014

\section{References}

1. Taylor F, Huffman MD, Macedo AF, Moore TH, Burke M, Davey Smith G, Ward K, Ebrahim S: Statins for the primary prevention of cardiovascular disease. Cochrane Database Syst Rev 2013, 1, CD004816.

2. Ross SD, Allen IE, Connelly JE, Korenblat BM, Smith ME, Bishop D, Luo D: Clinical outcomes in statin treatment trials: a meta-analysis. Arch Intern Med 1999, 159:1793-1802.

3. Thavendiranathan P, Bagai A, Brookhart MA, Choudhry NK: Primary prevention of cardiovascular diseases with statin therapy: a meta-analysis of randomized controlled trials. Arch Int Med 2006, 166:2307-2313.

4. Briel M, Studer M, Glass TR, Bucher HC: Effects of statins on stroke prevention in patients with and without coronary heart disease: a meta-analysis of randomized controlled trials. Am J Med 2004, 117:596-606.

5. LaRosa JC, He J, Vupputuri S: Effect of statins on risk of coronary disease: a meta-analysis of randomized controlled trials. JAMA 1999, 282:2340-2346.

6. Hebert PR, Gaziano JM, Chan KS, Hennekens CH: Cholesterol lowering with statin drugs, risk of stroke, and total mortality. An overview of randomized trials. JAMA 1997, 278:313-321.

7. Pitrou I, Boutron I, Ahmad N, Ravaud P: Reporting of safety results in published reports of randomized controlled trials. Arch Intern Med 2009, 169:1756-1761.

8. Baigent C, Keech A, Kearney PM, Blackwell L, Buck G, Pollicino C, Kirby A, Sourjina T, Peto R, Collins R, Simes R, Cholesterol Treatment Trialists' (CTT) Collaborators: Efficacy and safety of cholesterol-lowering treatment: prospective meta-analysis of data from 90,056 participants in 14 randomised trials of statins. Lancet 2005, 366:1267-1278. Erratum in: Lancet 2005, 366:1358. Lancet 2008, 371:2084.

9. Cholesterol Treatment Trialists' (CTT) Collaboration, Baigent C, Blackwell L, Emberson J, Holland LE, Reith C, Bhala N, Peto R, Barnes EH, Keech A, Simes J, Collins R: Efficacy and safety of more intensive lowering of LDL 
cholesterol: meta-analysis of data from 170,000 participants in 26 randomised trials. Lancet 2010, 376:1670-1681.

10. Cholesterol Treatment Trialists' (CTT) Collaborators, Mihaylova B, Emberson J, Blackwell L, Keech A, Simes J, Barnes EH, Voysey M, Gray A, Collins R, Baigent $C$ : The effects of lowering LDL cholesterol with statin therapy in people at low risk of vascular disease: meta-analysis of individual data from 27 randomised trials. Lancet 2012, 380:581-590.

11. Cholesterol Treatment Trialists' (CTT) Collaboration, Emberson JR, Kearney PM, Blackwell L, Newman C, Reith C, Bhala N, Holland L, Peto R, Keech A, Collins R, Simes J, Baigent C: Lack of effect of lowering LDL cholesterol on cancer: meta-analysis of individual data from 175,000 people in 27 randomised trials of statin therapy. PLoS One 2012, 7:e29849.

12. Sattar N, Preiss D, Murray HM, Welsh P, Buckley BM, de Craen AJ, Seshasai SR, McMurray JJ, Freeman DJ, Jukema JW, Macfarlane PW, Packard CJ, Stott DJ, Westendorp RG, Shepherd J, Davis BR, Pressel SL, Marchioli R, Marfisi RM, Maggioni AP, Tavazzi L, Tognoni G, Kjekshus J, Pedersen TR, Cook TJ, Gotto AM, Clearfield MB, Downs JR, Nakamura H, Ohashi Y, et al: Statins and risk of incident diabetes: a collaborative meta-analysis of randomised statin trials. Lancet 2010, 375:735-742.

13. Mills EJ, Wu P, Chong G, Ghement I, Singh S, Akl EA, Eyawo O, Guyatt G, Berwanger $\mathrm{O}$, Briel M: Efficacy and safety of statin treatment for cardiovascular disease: a network meta-analysis of 170,255 patients from 76 randomized trials. QJM 2011, 104:109-124.

14. FDA expands advice on statin risks. [www.fda.gov/ForConsumers/ ConsumerUpdates/ucm293330.htm]

15. Statins: risk of hyperglycaemia and diabetes. Drug safety update January 2012. 5:A2 [http://www.mhra.gov.uk/Safetyinformation/DrugSafetyUpdate/ CON140667]

16. Feng L, Yap KB, Kua EH, Ng TP: Statin use and depressive symptoms in a prospective study of community-living older persons. Pharmacoepidemiol Drug Saf 2010, 19:942-948.

17. Yang CC, Jick SS, Jick H: Lipid-lowering drugs and the risk of depression and suicidal behavior. Arch Intern Med 2003, 163:1926-1932.

18. Li G, Higdon R, Kukull WA, Peskind E, Van Valen Moore K, Tsuang D, van Belle G, McCormick W, Bowen JD, Teri L, Schellenberg GD, Larson EB: Statin therapy and risk of dementia in the elderly: a community-based prospective cohort study. Neurology 2004, 63:1624-1628

19. Bernick C, Katz R, Smith NL, Rapp S, Bhadelia R, Carlson M, Kuller L, Cardiovascular Health Study: Statins and cognitive function in the elderly: the Cardiovascular Health Study. Neurology 2005, 65:1388-1394.

20. McGwin G, Modjarrad K, Andrew Hal T, Xie A, Owsley C: 3-Hydroxy-3methylglutaryl coenzyme a reductase inhibitors and the presence of age-related macular degeneration in the cardiovascular health study. Arch Ophthalmol 2006, 124:33-37.

21. McCarty CA, Mukesh BN, Guymer RH, Baird PN, Taylor HR: Cholesterol-lowering medications reduce the risk of age-related maculopathy progression. Med J Aust 2001, 175:340.

22. Scott HD, Laake K: Statins for the prevention of Alzheimer's disease and dementia. Cochrane Database Syst Rev 2001, CD003160

23. McGuinness B, O'Hare J, Craig D, Bullock R, Malouf R, Passmore P: Statins for the treatment of dementia. Cochrane Database Syst Rev 2010, CD007514.

24. Gehlbach P, Li T, Hatef E: Statins for age-related macular degeneration. Cochrane Database Syst Rev 2012, CD006927.

25. Wang J, Xiao Y, Luo M, Luo H: Statins for multiple sclerosis. Cochrane Database Syst Rev 2011, CD008386.

26. Li L, Sun T, Zhang P, Tian J, Yang K: Statins for primary prevention of venous thromboembolism. Cochrane Database Syst Rev 2011, CD008203.

27. Rahimi K, Emberson J, McGale P, Majoni W, Merhi A, Asselbergs FW, Krane V, Macfarlane PW, PROSPER Executive: Effect of statins on atrial fibrillation: collaborative meta-analysis of published and unpublished evidence from randomised controlled trials. BMJ 2011, 342:d1250.

28. Heart Protection Study Collaborative Group, Bulbulia R, Bowman L Wallendszus K, Parish S, Armitage J, Peto R, Collins R: Effects on 11-year mortality and morbidity of lowering LDL cholesterol with simvastatin for about 5 years in 20,536 high-risk individuals: a randomised controlled trial. Lancet 2011, 378:2013-2020.

29. ClinicalEvidence: Learn, teach, and practise evidence-based medicine. [http://clinicalevidence.bmi.com/x/set/static/ebm/learn/665076.html]

30. Golder S, Loke YK: Sensitivity and precision of adverse effects search filters in MEDLINE and EMBASE: a case study of fractures with thiazolidinediones. Health Info Libr J 2012, 29:28-38.
31. Higgins JPT, Green S: Cochrane Handbook for Systematic Reviews of Interventions, Version 5.0.2 [updated September 2009]. The Cochrane Collaboration. Chichester, UK: John Wiley \& Sons, Ltd; 2009 [www.cochrane-handbook.org]

32. Egger M, Smith GD, Phillips AN: Meta-analysis: principles and procedures. BMJ 1997, 315:1533-1537.

33. Anderson JL, Muhlestein JB, Bair TL, Morris S, Weaver AN, Lappé DL, Renlund DG, Pearson RR, Jensen KR, Horne BD: Do statins increase the risk of idiopathic polyneuropathy? Am J Cardiol 2005, 95:1097-1099.

34. Ashfield TA, Syddall HE, Martin HJ, Dennison EM, Cooper C, Aihie Sayer A: Grip strength and cardiovascular drug use in older people: findings from the Hertfordshire Cohort Study. Age Ageing 2010, 39:185-191.

35. Atthobari J, Brantsma AH, Gansevoort RT, Visser ST, Asselbergs FW, van Gilst WH, de Jong PE, de Jong-van den Berg LT, PREVEND study group: The effect of statins on urinary albumin excretion and glomerular filtration rate: results from both a randomized clinical trial and an observational cohort study. Nephrol Dial Transplant 2006, 21:3106-3114

36. Becker C, Jick SS, Meier CR: Use of statins and the risk of Parkinson's disease: a retrospective case-control study in the UK. Drug Saf 2008, 31:399-407.

37. Chan KA, Andrade SE, Boles M, Buist DS, Chase GA, Donahue JG, Goodman MJ, Gurwitz JH, LaCroix AZ, Platt R: Inhibitors of hydroxymethylglutaryl-coenzyme A reductase and risk of fracture among older women. Lancet 2000, 355:2185-2188

38. Clockaerts S, Van Osch GJ, Bastiaansen-Jenniskens YM, Verhaar JA, Van Glabbeek F, Van Meurs JB, Kerkhof HJ, Hofman A, Stricker BH, Bierma-Zeinstra SM: Statin use is associated with reduced incidence and progression of knee osteoarthritis in the Rotterdam study. Ann Rheum Dis 2012, 71:642-647.

39. Corrao G, Zambon A, Bertù L, Botteri E, Leoni O, Contiero P: Lipid lowering drugs prescription and the risk of peripheral neuropathy: an exploratory case-control study using automated databases. J Epidemiol Community Health 2004, 58:1047-1051

40. Cramer C, Haan MN, Galea S, Langa KM, Kalbfleisch JD: Use of statins and incidence of dementia and cognitive impairment without dementia in a cohort study. Neurology 2008, 71:344-350.

41. Culver AL, Ockene IS, Balasubramanian R, Olendzki BC, Sepavich DM, Wactawski-Wende J, Manson JE, Qiao Y, Liu S, Merriam PA, Rahilly-Tierny C, Thomas F, Berger JS, Ockene JK, Curb JD, Ma Y: Statin use and risk of diabetes mellitus in postmenopausal women in the Women's Health Initiative. Arch Intern Med 2012, 172:144-152.

42. de Jong HJ, Klungel $\mathrm{OH}$, van Dijk L, Vandebriel RJ, Leufkens $H G$, van der Laan JW, Cohen Tervaert JW, van Loveren H: Use of statins is associated with an increased risk of rheumatoid arthritis. Ann Rheum Dis 2012, 71:648-654.

43. de Vries F, de Vries C, Cooper C, Leufkens B, van Staa TP: Reanalysis of two studies with contrasting results on the association between statin use and fracture risk: the General Practice Research Database. Int J Epidemiol 2006, 35:1301-1308

44. Doggen CJ, Lemaitre RN, Smith NL, Heckbert SR, Psaty BM: HMG CoA reductase inhibitors and the risk of venous thrombosis among post-menopausal women. J Thromb Haemost 2004, 2:700-701.

45. Erichsen R, Frøslev T, Lash TL, Pedersen L, Sorensen HT: Long-term statin use and the risk of gallstone disease: a population-based case-control study. Am J Epidemiol 2011, 173:162-170.

46. Fleming DM, Verlander NQ, Elliot AJ, Zhao H, Gelb D, Jehring D, Nguyen-VanTam JS: An assessment of the effect of statin use on the incidence of acute respiratory infections in England during winters 1998-1999 to 2005-2006. Epidemiol Infect 2010, 138:1281-1288.

47. Fuji T, Nakabayashi T, Hashimoto S, Kuwano H: Statin use and risk of gastroduodenal ulcer and reflux esophagitis. Hepatogastroenterology 2009, 56:641-644.

48. Gaist D, Garcia Rodriguez LA, Huerta C, Hallas J, Sindrup SH: Are users of lipid-lowering drugs at increased risk of peripheral neuropathy? Eur J Clin Pharmacol 2001, 56:931-933.

49. Gaist D, Jeppesen U, Andersen M, García Rodríguez LA, Hallas J, Sindrup SH: Statins and risk of polyneuropathy: a case-control study. Neurology 2002, 58:1333-1337.

50. Gaist D, Rodriguez LA, Huerta C, Hallas J, Sindrup SH: Lipid-lowering drugs and risk of myopathy: a population-based follow-up study. Epidemiology 2001, 12:565-569.

51. Gao X, Simon K, Schwarzschild MA, Ascherio A: A prospective study of statin use and risk of Parkinson disease. Parkinsonism Relat D 2012, 18:S40. 
52. Green RC, McNagny SE, Jayakumar P, Cupples LA, Benke K, Farrer LA MIRAGE Study Group: Statin use and the risk of Alzheimer's disease: the MIRAGE study. Alzheimers Dement 2006, 2:96-103.

53. Gulmez SE, Lassen AT, Aalykke C, Dall M, Andries A, Andersen BS, Hansen $J M$, Andersen $M$, Hallas J: Do statins protect against upper gastrointestinal bleeding? Br J Clin Pharmacol 2009, 67:460-465.

54. Haag MD, Hofman A, Koudstaal PJ, Stricker BH, Breteler MM: Statins are associated with a reduced risk of Alzheimer disease regardless of lipophilicity. The Rotterdam Study. J Neurol Neurosurg Psychiatry 2009, 80:13-17.

55. Hippisley-Cox J, Coupland C: Unintended effects of statins in men and women in England and Wales: population based cohort study using the QResearch database. BMJ 2010, 340:c2197.

56. Huang $X$, Chen H, Miller WC, Mailman RB, Woodard JL, Chen PC, Xiang D, Murrow RW, Wang YZ, Poole C: Lower low-density lipoprotein cholesterol levels are associated with Parkinson's disease. Mov Disord 2007, 22:377-381.

57. Huerta C, Johansson S, Wallander MA, Garcia Rodrıguez LA: Risk factors and short-term mortality of venous thromboembolism diagnosed in the primary care setting in the United Kingdom. Arch Intern Med 2007, 167:935-943.

58. Jick H, Zornberg GL, Jick SS, Seshadri S, Drachman DA: Statins and the risk of dementia. Lancet 2000, 356:1627-1631

59. Jick SS, Bradbury BD: Statins and newly diagnosed diabetes. $\mathrm{Br} J$ Clin Pharmacol 2004, 58:303-309.

60. Jick SS, Choi H, Li L, Mclnnes IB, Sattar N: Hyperlipidaemia, statin use and the risk of developing rheumatoid arthritis. Ann Rheum Dis 2009, 68:546-551.

61. Klein $B E$, Klein $R$, Lee KE, Grady LM: Statin use and incident nuclear cataract. JAMA 2006, 295:2752-2758.

62. Klein R, Klein BE, Tomany SC, Danforth LG, Cruickshanks KJ: Relation of statin use to the 5-year incidence and progression of age-related maculopathy. Arch Ophthalmol 2003, 121:1151-1155.

63. Klein R, Knudtson MD, Klein BE: Statin use and the five-year incidence and progression of age-related macular degeneration. Am J Ophthalmol 2007, 144:1-6.

64. Kwong JC, Li P, Redelmeier DA: Influenza morbidity and mortality in elderly patients receiving statins: a cohort study. PLOS One 2009, 4:e8087.

65. LaCroix AZ, Cauley JA, Pettinger M, Hsia J, Bauer DC, McGowan J, Chen Z, Lewis CE, McNeeley SG, Passaro MD, Jackson RD: Statin use, clinical fracture, and bone density in postmenopausal women: results from the Women's Health Initiative Observational Study. Ann Intern Med 2003, 139:97-104.

66. LaCroix AZ, Gray SL, Aragaki A, Cochrane BB, Newman AB, Kooperberg CL, Black $H$, Curb JD, Greenland P, Woods NF: Statin use and incident frailty in women aged 65 years or older: prospective findings from the Women's Health Initiative Observational Study. J Gerontol A Biol Sci Med Sci 2008, 63:369-375.

67. Lacut K, Le Gal G, Abalain JH, Mottier D, Oger E: Differential associations between lipid-lowering drugs, statins and fibrates, and venous thromboembolism: role of drug induced homocysteinemia? Thromb Res 2008, 122:314-319.

68. Lemaitre RN, Psaty BM, Heckbert SR, Kronmal RA, Newman AB, Burke GL: Therapy with hydroxymethylglutaryl coenzyme a reductase inhibitors (statins) and associated risk of incident cardiovascular events in older adults: evidence from the Cardiovascular Health Study. Arch Intern Med 2002, 162:1395-1400.

69. Li G, Shofer JB, Rhew IC, Kukull WA, Peskind ER, McCormick W, Bowen JD, Schellenberg GD, Crane PK, Breitner JC, Larson EB: Age-varying association between statin use and incident Alzheimer's disease. J Am Geriatr Soc 2010, 58:1311-1317

70. Luijendijk HJ, Stricker BH, Hofman A, Witteman JCM, Tiemeier H: Cerebrovascular risk factors and incident depression in community-dwelling elderly. Acta Psychiatr Scand 2008, 118:139-148.

71. Marcus MW, Müskens RP, Ramdas WD, Wolfs RC, De Jong PT, Vingerling JR, Hofman A, Stricker BH, Jansonius NM: Cholesterol-lowering drugs and incident open-angle glaucoma: a population-based cohort study. PLOS ONE 2012, 7:e29724.

72. McClure DL, Valuck RJ, Glanz M, Murphy JR, Hokanson JE: Statin and statin-fibrate use was significantly associated with increased myositis risk in a managed care population. J Clin Epidemiol 2007, 60:812-818.

73. McGwin G Jr, Owsley C, Curcio CA, Crain RJ: The association between statin use and age related maculopathy. Br J Ophthalmol 2003, 87:1121-1125.

74. McGwin G Jr, McNeal S, Owsley C, Girkin C, Epstein D, Lee PP: Statins and other cholesterol-lowering medications and the presence of glaucoma. Arch Ophthalmol 2004, 122:822-826.

75. Meier CR, Schlienger RG, Kraenzlin ME, Schlegel B, Jick H: HMG-CoA reductase inhibitors and the risk of fractures. JAMA 2000, 283:3205-3210.
76. Myles PR, Hubbard RB, McKeever TM, Pogson Z, Smith CJ, Gibson JE: Risk of community-acquired pneumonia and the use of statins, ace inhibitors and gastric acid suppressants: a population-based case-control study. Pharmacoepidemiol Drug Saf 2009, 18:269-275.

77. Nash SD, Cruickshanks KJ, Klein R, Klein BE, Nieto FJ, Huang GH, Pankow JS, Tweed TS: The prevalence of hearing impairment and associated risk factors: the Beaver Dam Offspring Study. Arch Otolaryngol Head Neck Surg 2011, 137:432-439.

78. Nichols GA, Koro CE: Does statin therapy initiation increase the risk for myopathy? An observational study of 32,225 diabetic and nondiabetic patients. Clin Ther 2007, 29:1761-1770.

79. Owen CG, Carey IM, Shah S, de Wilde S, Wormald R, Whincup PH, Cook DG: Hypotensive medication, statins, and the risk of glaucoma. Invest Ophthalmol Vis Sci 2010, 51:3524-3530.

80. Ramcharan AS, van Stralen KJ, Snoep JD, Mantel-Teeuwisse AK, Rosendaal FR, Doggen CJ: HMG-CoA reductase inhibitors are associated with a reduced risk of venous thrombosis. J Thromb Haemost 2009, 7:514-520

81. Ray WA, Daugherty JR, Griffin MR: Lipid-lowering agents and the risk of hip fracture in a Medicaid population. Inj Prev 2002, 8:276-279.

82. Rea TD, Breitner JC, Psaty BM, Fitzpatrick AL, Lopez OL, Newman AB, Hazzard WR, Zandi PP, Burke GL, Lyketsos CG, Bernick C, Kuller LH: Statin use and the risk of incident dementia: the Cardiovascular Health Study. Arch Neurol 2005, 62:1047-1051.

83. Rejnmark L, Olsen ML, Johnsen SP, Vestergaard P, Sørensen HT, Mosekilde L: Hip fracture risk in statin users-a population-based Danish case-control study. Osteoporos Int 2004, 15:452-458.

84. Risselada R, Straatman H, van Kooten F, Dippel DW, van der Lugt A, Niessen WJ, Firouzian A, Herings RM, Sturkenboom MC: Withdrawal of statins and risk of subarachnoid hemorrhage. Stroke 2009, 40:2887-2892.

85. Ritz B, Manthripragada AD, Qian L, Schernhammer E, Wermuth L, Olsen J, Friis S: Statin use and Parkinson's disease in Denmark. Mov Disord 2010, 25:1210-1216.

86. Rockwood K, Howlett S, Fisk J, Darvesh S, Tuokko H, Hogan DB, Wolfson C, McDowell I: Lipid-lowering agents and the risk of cognitive impairment that does not meet criteria for dementia, in relation to apolipoprotein $\mathrm{E}$ status. Neuroepidemiology 2007, 29:201-207.

87. Rockwood K, Kirkland S, Hogan DB, Macknight C, Merry H, Verreault R, Wolfson C, McDowell I: Use of lipid-lowering agents, indication bias, and the risk of dementia in community-dwelling elderly people. Arch Neurol 2002, 59:223-227.

88. Rodríguez GL, Wallander MA, Tolosa LB, Johansson S: Chronic obstructive pulmonary disease in UK primary care: incidence and risk factors. COPD 2009, 6:369-379.

89. Schlienger RG, Fedson DS, Jick SS, Jick H, Meier CR: Statins and the risk of pneumonia: a population-based, nested case-control study. Pharmacotherapy 2007, 27:325-332.

90. Schlienger RG, Haefeli WE, Jick H, Meier CR: Risk of cataract in patients treated with statins. Arch Intern Med 2001, 161:2021-2026.

91. Schoofs MW, Sturkenboom MC, van der Klift M, Hofman A, Pols HA, Stricker $\mathrm{BH}$ : HMG-CoA reductase inhibitors and the risk of vertebral fracture. J Bone Miner Res 2004, 19:1525-1530.

92. Scranton RE, Young M, Lawler L, Solomon DH, Gagnon DR, Gaziano JM: Statin use and fracture risk: study of a US veterans population. Arch Intern Med 2005, 165:2007-2012.

93. Smeeth L, Cook C, Chakravarthy U, Hubbard R, Fletcher AE: A case control study of age related macular degeneration and use of statins. $\mathrm{Br} J$ Ophthalmol 2005, 89:1171-1175.

94. Smeeth L, Douglas I, Hall AJ, Hubbard R, Evans S: Effect of statins on a wide range of health outcomes: a cohort study validated by comparison with randomized trials. Br J Clin Pharmacol 2009, 67:99-109.

95. Smeeth L, Hubbard R, Fletcher AE: Cataract and the use of statins: a case-control study. QJM 2003, 96:337-343.

96. Solomon A, Kåreholt I, Ngandu T, Wolozin B, MacDonald SW, Winblad B, Nissinen A, Tuomilehto J, Soininen H, Kivipelto M: Serum total cholesterol, statins and cognition in non-demented elderly. Neurobiol Aging 2009, 30:1006-1009.

97. Sørensen HT, Horvath-Puho E, Søgaard KK, Christensen S, Johnsen SP, Thomsen RW, Prandoni P, Baron JA: Arterial cardiovascular events, statins, low dose aspirin and subsequent risk of venous thromboembolism: a populationbased case-control study. J Thromb Haemost 2009, 7:521-528.

98. Sørensen HT, Riis AH, Lash TL, Pedersen L: Statin use and risk of amyotrophic lateral sclerosis and other motor neuron disorders. Circ Cardiovasc Qual Outcomes 2010, 3:413-417. 
99. St Sauver JL, Jacobsen SJ, Jacobson DJ, McGree ME, Girman CJ, Girman CJ, Nehra A, Roger $\mathrm{VL}$, Lieber MM: Statin use and decreased risk of benign prostatic enlargement and lower urinary tract symptoms. BJU Int 2011, 107:443-450.

100. Sukhija R, Bursac Z, Kakar P, Fink L, Fort C, Satwani S, Aronow WS, Bansal D, Mehta JL: Effect of statins on the development of renal dysfunction. Am J Cardio/ 2008, 101:975-979.

101. Szwast SJ, Hendrie HC, Lane KA, Gao S, Taylor SE, Unverzagt F, Murrell J, Deeg M, Ogunniyi A, Farlow MR, Hall KS: Association of statin use with cognitive decline in elderly African Americans. Neurology 2007, 69:1873-1880.

102. Tan JS, Mitchell P, Rochtchina E, Wang JJ: Statin use and the long-term risk of incident cataract: the Blue Mountains Eye Study. Am J Ophthalmol 2007, 143:687-689.

103. Tan JS, Mitchell P, Rochtchina E, Wang JJ: Statins and the long-term risk of incident age-related macular degeneration: the Blue Mountains Eye Study. Am J Ophthalmol 2007, 143:685-687.

104. Tsai C-J, Leitzmann MF, Willett WC, Giovannucci EL: Statin use and the risk of cholecystectomy in women. Gastroenterology 2009, 136:1593-1600.

105. van Leeuwen R, Vingerling JR, Hofman A, de Jong PT, Stricker BH: Cholesterol lowering drugs and risk of age related maculopathy: prospective cohort study with cumulative exposure measurement. BMJ 2003, 326:255-256

106. van Leeuwen R, Tomany SC, Wang JJ, Klein R, Mitchell P, Hofman A, Klein $B E$, Vingerling JR, Cumming RG, de Jong PT: Is medication use associated with the incidence of early age-related maculopathy? Pooled findings from 3 continents. Ophthalmology 2004, 111:1169-1175.

107. van Staa T, Wegman S, de Vries F, Leufkens B, Cooper C: Use of statins and risk of fractures. JAMA 2001, 285:1850-1855

108. Wahner AD, Bronstein JM, Bordelon YM, Ritz B: Statin use and the risk of Parkinson disease. Neurology 2008, 70:1418-1422.

109. Wang PS, Solomon DH, Mogun H, Avorn J: HMG-CoA reductase inhibitors and the risk of hip fractures in elderly patients. JAMA 2000, 283:3211-3216.

110. Woo D, Kissela BM, Khoury JC, Sauerbeck LR, Haverbusch MA, Szaflarski JP, Gebel JM, Pancioli AM, Jauch EC, Schneider A, Kleindorfer D, Broderick JP: Hypercholesterolemia, HMG-CoA reductase inhibitors, and risk of intracerebral hemorrhage: a case-control study. Stroke 2004, 35:1360-1364.

111. Yang C-C, Jick SS, Jick H: Statins and the risk of idiopathic venous thromboembolism. Br J Clin Pharmacol 2002, 53:101-105.

112. Yang CC, Kao CC: Cardiovascular diseases and the risk of venous thromboembolism: a hospital-based case-control study. J Chin Med Assoc 2007, 70:103-109.

113. Zamrini E, McGwin G, Roseman JM: Association between statin use and Alzheimer's disease. Neuroepidemiology 2004, 23:94-98.

114. Zandi PP, Sparks DL, Khachaturian AS, Tschanz J, Norton M, Steinberg M, Welsh-Bohmer KA, Breitner JC, Cache County Study investigators: Do statins reduce risk of incident dementia and Alzheimer disease? The Cache County Study. Arch Gen Psychiatry 2005, 62:217-224.

115. Golder S, Loke YK, Bland M: Meta-analyses of adverse effects data derived from randomised controlled trials as compared to observational studies: methodological overview. PLoS Med 2011, 8:e1001026.

116. O'Neil A, Sanna L, Redlich C, Sanderson K, Jacka F, Williams LJ, Pasco JA Berk M: The impact of statins on psychological wellbeing: a systematic review and meta-analysis. BMC Med 2012, 10:154.

117. Toh S, Hernández-Díaz S: Statins and fracture risk. A systematic review. Pharmacoepidemiol Drug Saf 2007, 16:627-640.

118. Sandhu S, Wiebe N, Fried LF, Tonelli M: Statins for improving renal outcomes: a meta-analysis. J Am Soc Nephrol 2006, 17:2006-2016.

119. Rahimi K, Bhala N, Kamphuisen P, Emberson J, Biere-Rafi S, Krane V, Robertson M, Wikstrand J, McMurray J: Effect of statins on venous thromboembolic events: a meta-analysis of published and unpublished evidence from randomised controlled trials. PLoS Med 2012, 9:e1001310.

120. Swiger KJ, Manalac RJ, Blumenthal RS, Blaha MJ, Martin SS: Statins and cognition: a systematic review and meta-analysis of short- and long-term cognitive effects. Mayo Clin Proc 2013, 88:1213-1221.

121. Richardson K, Schoen M, French B, Umscheid CA, Mitchell MD, Arnold SE, Heidenreich PA, Rader DJ, de Goma EM: Statins and cognitive function: a systematic review. Ann Int Med 2013, 159:688-697.

122. Kwok CS, Yeong JK, Turner RM, Cavallazzi R, Singh S, Loke YK: Statins and associated risk of pneumonia: a systematic review and meta-analysis of observational studies. Eur J Clin Pharmacol 2012, 68:747-755.

123. Novack V, MacFadyen J, Malhotra A, Almog Y, Glynn R, Ridker PM: The effect of rosuvastatin on incident pneumonia: results from the JUPITER trial. CMAJ 2012, 184:E367-E372.
124. Chopra V, Flanders SA: Does statin use improve pneumonia outcomes? Chest 2009, 136:1381-1388.

125. Preiss D, Seshasai SR, Welsh P, Murphy SA, Ho JE, Waters DD, DeMicco DA, Barter P, Cannon CP, Sabatine MS, Braunwald E, Kastelein JJ, de Lemos JA, Blazing MA, Pedersen TR, Tikkanen MJ, Sattar N, Ray KK: Risk of incident diabetes with intensive-dose compared with moderate-dose statin therapy: a meta-analysis. JAMA 2011, 305:2556-2564.

126. Waters DD, Ho JE, de Micco DA, Breazna A, Arsenault BJ, Wun CC, Kastelein $\mathrm{J}$, Colhoun H, Barter P: Predictors of new-onset diabetes in patients treated with atorvastatin: results from 3 large randomized clinical trials. J Am Coll Cardiol 2011, 57:1535-1545.

127. Carter AA, Gomes T, Camacho X, Juurlink DN, Shah BR, Mamdani MM: Risk of incident diabetes among patients treated with statins: population based study. BMJ. 2013, 346:f2610.

128. Ridker PM, Pradhan A, MacFadyen JG, Libby P, Glynn RJ: Cardiovascular benefits and diabetes risks of statin therapy in primary prevention: an analysis from the JUPITER trial. Lancet 2012, 380:565-571.

129. Nakata M, Nagasaka S, Kusaka I, Matsuoka H, Ishibashi S, Yada T: Effects of statins on the adipocyte maturation and expression of glucose transporter 4 (SLC2A4): implications in glycaemic control. Diabetologia 2006, 49:1881-1892.

130. Kruit JK, Kremer PH, Dai L, Tang R, Ruddle P, de Haan W, Brunham LR, Verchere CB, Hayden MR: Cholesterol efflux via ATP-binding cassette transporter $A 1$ (ABCA1) and cholesterol uptake via the LDL receptor influences cholesterol-induced impairment of beta cell function in mice. Diabetologia 2010, 53:1110-1119.

131. Koh KK, Sakuma I, Quon MJ: Differential metabolic effects of distinct statins. Atherosclerosis 2011, 215:1-8.

132. Law M, Rudnicka AR: Statin safety: a systematic review. Am J Cardiol 2006, 97:52C-60C

133. Parker BA, Capizzi JA, Grimaldi AS, Clarkson PM, Cole SM, Keadle J, Chipkin S, Pescatello LS, Simpson K, White CM, Thompson PD: Effect of statins on skeletal muscle function. Circulation 2013, 127:96-103.

134. Mansi I, Frei CR, Pugh MJ, Makris U, Mortensen EM: Statins and musculoskeletal conditions, arthropathies, and injuries. JAMA 2013, 173:1-10.

135. Palmer SC, Craig JC, Navaneethan SD, Tonelli M, Pellegrini F, Strippoli GF: Benefits and harms of statin therapy for persons with chronic kidney disease: a systematic review and meta-analysis. Ann Int Med 2012, 157:263-275.

136. Upadhyay A, Earley A, Lamont JL, Haynes S, Wanner C, Balk EM: Lipid-lowering therapy in persons with chronic kidney disease: a systematic review and meta-analysis. Ann Int Med 2012, 157:251-262.

137. Armitage J: The safety of statins in clinical practice. Lancet 2007 370:1781-1790.

138. Naci H, Brugts J, Ades T: Comparative tolerability and harms of individual statins: a study-level network meta-analysis of 246955 participants from 135 randomized, controlled trials. Circ Cardiovasc Qual Outcomes 2013, 6:390-399.

139. Hackam DG, Woodward M, Newby LK, Bhatt DL, Shao M, Smith EE, Donner A, Mamdani M, Douketis JD, Arima H, Chalmers J, MacMahon S, Tirschwell DL, Psaty BM, Bushnell CD, Aguilar MI, Capampangan DJ, Werring DJ, De Rango P, Viswanathan A, Danchin N, Cheng CL, Yang YH, Verdel BM, Lai MS, Kennedy J, Uchiyama S, Yamaguchi T, Ikeda Y, Mrkobrada M: Statins and intracerebral hemorrhage: collaborative systematic review and meta-analysis. Circulation 2011, 124:2233-2242.

140. Reiner Z: Statins in the primary prevention of cardiovascular disease. Nat Rev Cardiol 2013, 10:453-464

141. van Staa TJ, Smeeth L, Ng ES, Goldacre B, Gulliford M: The efficiency of cardiovascular risk assessment: do the right patients get statin treatment? Heart 2013, 99:1597-1602.

142. Lonn E, Bosch J, Teo KK, Pais P, Xavier D, Yusuf S: The polypill in the prevention of cardiovascular diseases: key concepts, current status, challenges, and future directions. Circulation 2010, 122:2078-2088.

doi:10.1186/1741-7015-12-51

Cite this article as: Macedo et al:: Unintended effects of statins from observational studies in the general population: systematic review and meta-analysis. BMC Medicine 2014 12:51 